\title{
Telomere erosion in NF1 tumorigenesis
}

Research Paper

\author{
Rhiannon E. Jones ${ }^{1}$, Julia W. Grimstead ${ }^{1}$, Ashni Sedani ${ }^{1}$, Duncan Baird ${ }^{1}$ and Meena \\ Upadhyaya ${ }^{1}$ \\ ${ }^{1}$ Division of Cancer and Genetics, Cardiff University, Heath Park, Cardiff, CF14 4XN, UK \\ Correspondence to: Meena Upadhyaya, email: upadhyaya@cardiff.ac.uk \\ Keywords: telomere, NFI, MPNST, genetic instability, cancer \\ Received: November 02, $2016 \quad$ Accepted: March 02, $2017 \quad$ Published: April 09, 2017
}

Copyright: Jones et al. This is an open-access article distributed under the terms of the Creative Commons Attribution License 3.0 (CC BY 3.0), which permits unrestricted use, distribution, and reproduction in any medium, provided the original author and source are credited.

\section{ABSTRACT}

Neurofibromatosis type 1 (NF1; MIM\# 162200) is a familial cancer syndrome that affects 1 in 3,500 individuals worldwide and is inherited in an autosomal dominant fashion. Malignant Peripheral Nerve Sheath Tumors (MPNSTs) represent a significant cause of morbidity and mortality in NF1 and currently there is no treatment or definite prognostic biomarkers for these tumors. Telomere shortening has been documented in numerous tumor types. Short dysfunctional telomeres are capable of fusion and it is considered that the ensuing genomic instability may facilitate clonal evolution and the progression to malignancy. To evaluate the potential role of telomere dysfunction in NF1-associated tumors, we undertook a comparative analysis of telomere length in samples derived from 10 cutaneous and $\mathbf{1 0}$ diffused plexiform neurofibromas, and 19 MPNSTs. Telomere length was determined using high-resolution Single Telomere Length Analysis (STELA). The mean Xp/Yp telomere length detected in MPNSTs, at $3.282 \mathbf{~ k b}$, was significantly shorter than that observed in both plexiform neurofibromas (5.793 kb; $[p=0.0006])$ and cutaneous neurofibromas (6.141 kb; $[p=0.0007])$. The telomere length distributions of MPNSTs were within the length-ranges in which telomere fusion is detected and that confer a poor prognosis in other tumor types. These data indicate that telomere length may play a role in driving genomic instability and clonal progression in NF1-associated MPNSTs.

\section{INTRODUCTION}

Neurofibromatosis type 1 (NF1; MIM\# 162200) is a familial cancer syndrome that affects 1 in 3,500 individuals worldwide, it is inherited in an autosomal dominant fashion and is caused by inactivation of the NF1 tumor suppressor gene, located at 17q11.2. NF1 patients develop a variety of tumor types, including cutaneous neurofibromas, plexiform neurofibromas, malignant peripheral nerve sheath tumors, (MPNSTs), optic gliomas, phaechromocytomas, glomus tumors, gastrointestinal tumors and leukaemia [1]. While homozygous inactivation of the NF1 gene occurs in both the benign cutaneous and plexiform neurofibromas, as well as in MPNSTs, additional genetic, biochemical and cellular changes are clearly required for malignant transformation to occur in MPNSTs. Indeed, such tumors represent a significant cause of morbidity and mortality in NF1, with patients exhibiting an $8-13 \%$ lifetime risk of developing an
MPNST, often developing within a pre-existing plexiform neurofibroma, an atypical neurofibroma or a focal subcutaneous neurofibroma [2,3,4]. More than half of all MPNSTs diagnosed are found in association with NF1, with such patients usually exhibiting a poor prognosis in comparison to patients with a sporadic MPNST [5].

The presence of internal plexiform neurofibromas is strongly associated with MPNST development [6], with a high benign tumor burden also representing a risk factor for the development of MPNST. Other risk factors for the development of MPNST include the presence of an inherited gross deletion of the entire $N F 1$ gene region in 17q11.2 [7], previous radiation therapy [7], the presence of neurofibromatous neuropathy [8], as well as a family history of MPNSTs [9]. Unfortunately, many MPNSTs at first presentation, are already past surgical intervention as the diagnosed tumor has reached a late stage of development, with metastases commonly in the lungs, but also in the liver and brain. Thus, the 5-and 10- 
year survival rates for such affected NF1 individuals are only $20 \%-50 \%$ and $7.5 \%$, respectively. While there are no effective treatments for MPNSTs, complete surgical excision with clear margins, if possible, is the therapy of choice, with chemotherapy and radiotherapy also being employed despite its limited effectiveness.

Several studies have analyzed aspects of tumor DNA, RNA and proteins in the search for potential molecular signatures capable of differentiating between aggressive MPNSTs and benign neurofibromas [10-21]. We have previously shown, using different DNA array platforms that MPNSTs are associated with multiple gross DNA rearrangements, with both large deletions and amplifications observed $[11,12,15]$. Recently, wholegenome/exome sequencing analyses have revealed recurrent additional genetic alterations consisting of somatic loss-of-function mutations or deletions of the Polycomb repressive complex 2 (PRC2) subunits (EED or SUZ12) in the vast majority of sporadic, NF1-associated, and radiotherapy-associated MPNSTs [19, 20, 21]. From these data it is clear that MPNST development is a complex molecular genetic process in which multiple mutations of many genes, all contributing to deregulation of multiple signaling and regulatory pathways, is to be expected.

Early detection of MPNSTs would greatly facilitate the identification and clinical management of these affected NF1 patients, however despite numerous studies no definitive information on diagnostic and prognostic biomarkers associated with MPNST development is yet available $[15,17,18]$. Telomeres are structures that cap the ends of eukaryotic chromosome protecting the natural chromosome-end from recognition by the cellular DNA damage response [22]. Telomere shortening with on-going cell division leads to the uncapping of the telomere and the initiation of a Tp53 dependent G1-S cell-cycle arrest, that provides a limit on replicative lifespan [23]. However, in the absence of a fully functional DNA damage checkpoint response, short dysfunctional telomeres can be subjected to DNA repair activities that result in the fusion of telomeres with other telomeric or non-telomeric loci [24]; the resulting di-centric chromosomes initiate cycles of anaphase-bridging, breakage and fusion that lead to large-scale genomic rearrangements of the kind observed in many tumor types [25]. Telomere length has recently emerged as a powerful prognostic and predictive marker in several tumor types, including chronic lymphocytic leukemia (CLL) [26, 27) and breast cancer [28]. Our previous studies [29] identified increased telomerase activity in high grade MPNSTs but was not detectable in diffused plexiform neurofibromas or cutaneous neurofibromas, consistent with a role for telomere dysfunction during the progression of malignancy. In this study we have focused on the possible role that telomere length may play in NF1 tumorigenesis and to evaluate the potential of high-resolution telomere length analysis as a diagnostic and prognostic tool.

\section{RESULTS}

The telomere length distributions at XpYp were determined using STELA in 19 MPNSTs, 10 plexiform neurofibromas and 10 cutaneous neurofibromas (Fig. $1 \mathrm{~A}$ and supplementary figure). It was apparent from this analysis that the telomere length distributions of MPNSTs were distinct from those observed in both the plexiform and the cutaneous neurofibromas. The telomere lengths of 5 MPNSTs displayed clear bi-modal distributions; see for example, tumors 2 and 4 shown in Figure 1A. These telomere length distributions are consistent with the presence of either multiple clones within the same tumor, or the presence of normal somatic tissue within the sample. These two possibilities could not be formally distinguished and because our previous data from other tumor types [28, 30] show that tumors displaying shorter telomeres display a more aggressive phenotype, we used the mean of the lower telomere length distribution for these 5 tumors that exhibited a bimodal telomere length distribution. Overall the mean Xp/Yp telomere length detected in MPNSTs, was $3.282 \mathrm{~kb}$ and this was significantly shorter than that observed in both plexiform neurofibromas (5.793 kb; $[\mathrm{p}==0.0006]$ and cutaneous neurofibromas $(6.141 \mathrm{~kb}$; $[\mathrm{p}=0.0007]$ ) (Figure 1B). The telomere length profiles observed in plexiform neurofibromas and cutaneous neurofibromas were indistinguishable $[p=0.63]$. The telomere erosion observed in MPNSTs was extensive, with 15 of the 19 samples (79\%), displaying mean telomere length distributions that were less than the 3.81 $\mathrm{kb}$ telomere length threshold below which telomere fusion is detected and that confers a poor prognosis in both CLL and breast cancer [Figure 1B, 26, 28].

Using a variety of microarray platforms, we and others [10-15,5], have previously shown that DNA from MPNSTs exhibits significant large-scale genomic rearrangements, with both extensive DNA deletions and amplifications, and that these tumors also show significantly elevated levels of telomerase [29]. Owing to the limited data on samples used for telomere length profiles, we are unable to comment whether MPNSTs undergoing a period of genomic instability are driven by telomere dysfunction. A comparison between the telomere size and the genomic data derived from 13 MPNSTs from previous studies is shown in Table 1.

\section{DISCUSSION}

This study, the first to investigate the possible role of telomere length in the aetiology of NF1-associated tumors, indicates that high-resolution telomere length analysis could be important in understanding the molecular pathology of MPNSTs.

We have previously shown that the telomerase levels are elevated in MPNSTS compared to either benign cutaneous or plexiform neurofibromas [29]. To explore 

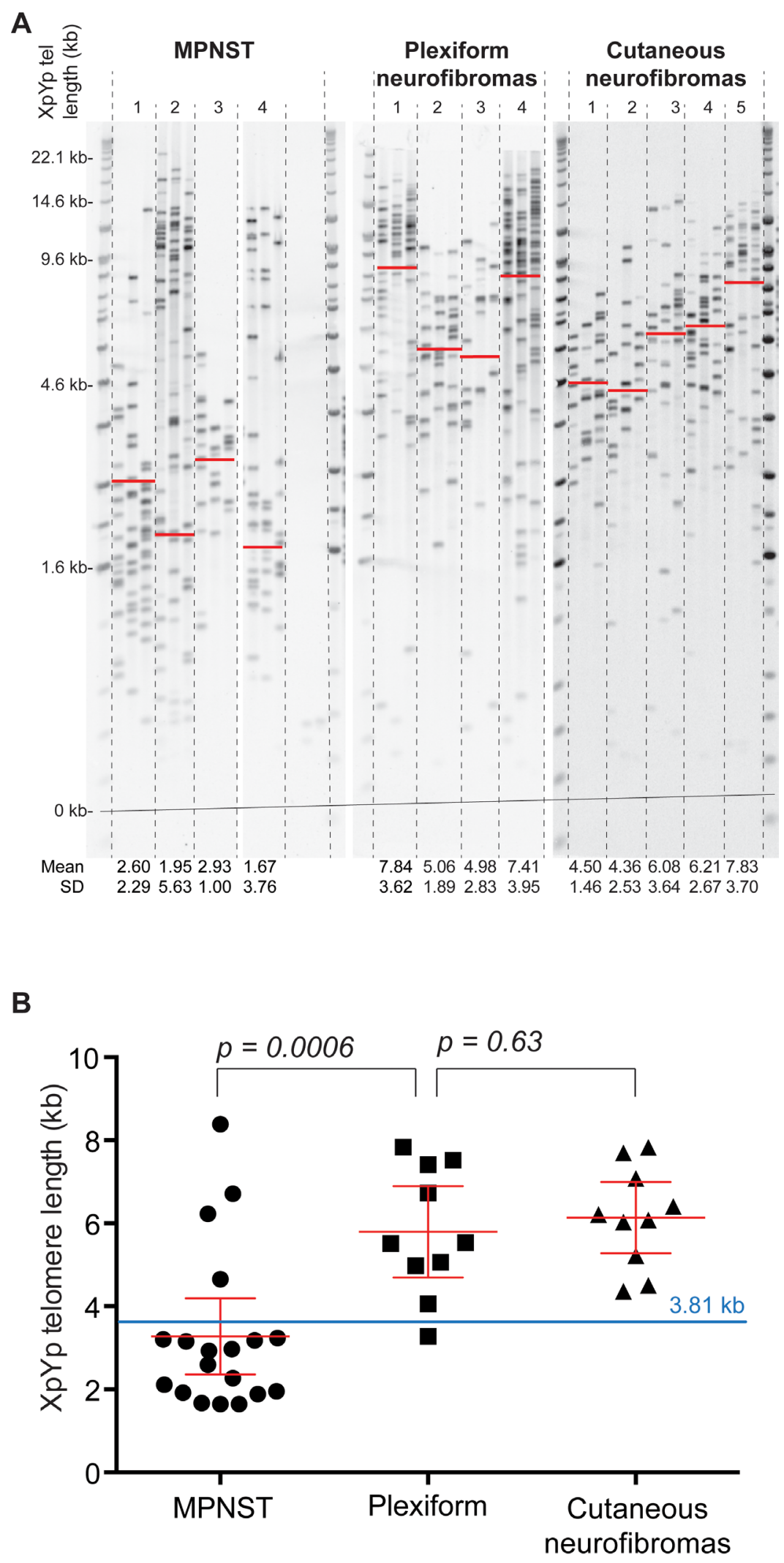

Figure 1: Telomere length distributions of MPNSTs are distinct from those observed in plexiform and cutaneous neurofibromas. A., example of XpYp STELA in 4 MPNSTs, 4 plexiform neurofibromas and 5 cutaneous neurofibromas. Mean telomere length and standard deviation are detailed below the gel image and indicated with a red on the gel image. For tumors that displayed a clear bimodal distribution the mean of lower modal distribution was calculated. B., scatter plot depicting mean XpYp telomere length in the three different tumor types as indicated below. The $3.81 \mathrm{~kb}$ telomere fusion threshold, previously defined in CLL (26) is depicted in blue. 
Table 1: Genomic Data on 13 NF1-associated MPNSTs.

\begin{tabular}{|c|c|c|c|c|c|c|c|c|}
\hline \multirow[b]{2}{*}{ ID } & \multirow[b]{2}{*}{ Grade } & \multirow[b]{2}{*}{$\begin{array}{l}\text { Telomere } \\
\text { Length }\end{array}$} & \multicolumn{2}{|c|}{ NF1 Mutations } & \multirow[b]{2}{*}{ p53 Mutations } & \multirow[b]{2}{*}{ Telomerase } & \multicolumn{2}{|l|}{ Target Array } \\
\hline & & & NF1 Germline & NF1 Somatic & & & Deleted & Amplified \\
\hline 1 & High & Short & c2002-14C >G & $\begin{array}{l}\text { LOH: I12b, IVS27, EVI20, } \\
\text { IVS38, 3'NF, Del Array CGH }\end{array}$ & $\mathrm{LOH}$ & Positive & $\begin{array}{l}\text { HMMR, MMP13, mTOR, } \\
\text { NF1, OSF2, p16-INK4a, } \\
\text { PTCH2, RB1, TP53 }\end{array}$ & $\begin{array}{l}\text { CCNE2, } \\
\text { SOX10, } \\
\text { TOP2A }\end{array}$ \\
\hline 2 & High & Short & Exon 2,3 Del & $\begin{array}{l}\text { LOH: Ex5, I12b, IVS27, } \\
\text { EVI20, IVS38, C\&CT, EW206, } \\
\text { EW207, 3'NF1;>2.2 Mb Del } \\
\text { Array CGH }\end{array}$ & $\mathrm{LOH}$ & Positive & $\begin{array}{l}\text { BLBP, HMMR, HSPCA, } \\
\text { Mki-67, MMP13, NF1, } \\
\text { p16-INK4a, PTEN, TP53 }\end{array}$ & $\begin{array}{l}\text { BIRC5, } \\
\text { CCND1, } \\
\text { EGFR, } \\
\text { ITGB4, } \\
\text { TERT, } \\
\text { TOP2A }\end{array}$ \\
\hline 3 & Low & Short & $\begin{array}{l}\text { c2497 2497delT,S8 } \\
33 \mathrm{fsX} \overline{8}\end{array}$ & Del Exon 1-4c, 6 & No & Not Done & NF1, TOP2A & FOXA2 \\
\hline 4 & High & Long & Not Found & c5788_5788delC & No & Positive & NF1 & $\begin{array}{l}\text { CCND1, } \\
\text { ITGB4, } \\
\text { MMP9, } \\
\text { PTCH2, } \\
\text { SOX10, } \\
\text { TERT, TP73, } \\
\text { TSC2 }\end{array}$ \\
\hline 5 & High & Short & $\begin{array}{l}\text { c3457 3460delCTC A, } \\
\text { L1153fsX4 }\end{array}$ & LOH -3'NF1: Del Array CGH & $\mathrm{LOH}$ & Positive & $\begin{array}{l}\text { EPHA7, FN1, HMMR, } \\
\text { Mki-67, MMP13, NF1, } \\
\text { p16-INK4a, RB1 }\end{array}$ & $\begin{array}{l}\text { BIRC5, } \\
\text { ITGB4, TERT }\end{array}$ \\
\hline 6 & High & Short & c5234 C > G, S1745X & $\begin{array}{l}\text { LOH: HHH202, I12b, IVS27, } \\
\text { EW206 }\end{array}$ & $\mathrm{LOH}$ & Positive & $\begin{array}{l}\text { HMMR, } \\
\text { LICAM2, MMP13, NF1, } \\
\text { RASSF2 }\end{array}$ & mTOR \\
\hline 7 & High & Long & $\mathrm{c} 5234 \mathrm{C}>\mathrm{G}, \mathrm{S} 1745 \mathrm{X}$ & $\begin{array}{l}\text { Partial Gene Deletion - Array } \\
\text { CGH }\end{array}$ & No & inconclusive & No Changes & No Changes \\
\hline 8 & Low & Long & $\mathrm{c} 1318 \mathrm{C}>\mathrm{T}, \mathrm{R} 440 \mathrm{X}$ & LOH: HHH202, EVI20. IVS38 & $\mathrm{LOH}$ & Negative & $\begin{array}{l}\text { BLBP, EPHA7, Mki-67, } \\
\text { MMP13, RASSF2 }\end{array}$ & TOP2A \\
\hline 9 & High & Short & Whole Gene Deletion & & $\mathrm{LOH}$ & Not Done & & \\
\hline 10 & Low & Long? & & & & Not Done & & \\
\hline 11 & High & Short & & & & & $\begin{array}{l}\text { HGF, HMMR, HSPCA, } \\
\text { LICAM2, MET, NF1, } \\
\text { OSF2, p16-INK4a, } \\
\text { RASSF2, RB1 }\end{array}$ & $\begin{array}{l}\text { EGFR, } \\
\text { ITGB4, } \\
\text { MMP9 }\end{array}$ \\
\hline 12 & Unknown & Short & & & & & $\begin{array}{l}\text { MMP13, NF1, RASSF2, } \\
\text { TP53 }\end{array}$ & $\begin{array}{l}\text { BIRC5, } \\
\text { CCNE2, } \\
\text { CCND1, } \\
\text { EGFR, FLT4, } \\
\text { FOXA2, } \\
\text { HGF, } \\
\text { HSPCA, } \\
\text { ITGB4, } \\
\text { MDM4, } \\
\text { MET, mTOR, } \\
\text { PDGFRA, } \\
\text { S108, TERT, } \\
\text { TOP2A, TP73 }\end{array}$ \\
\hline 13 & Unknown & Short & & & & & $\begin{array}{l}\text { BLBP, HMMR, MMP13, } \\
\text { NF1, OSF2, p16-INK4a, } \\
\text { RB1 }\end{array}$ & $\begin{array}{l}\text { CDKN18/ } \\
\text { p28, FLT4, } \\
\text { FOXM1, } \\
\text { RASSF2 } \\
\end{array}$ \\
\hline
\end{tabular}

Genomic data included in this Table has been taken from previous published reports: $[3,11,12,15,31,32]$

$\mathrm{LOH}$ - Loss of heterozygosity identified either with intragenic markers or by array CGH

CGH - Comparative Genomic Hybridisation

whether there was a potential correlation between telomere length and telomerase expression, we used the telomerase data available for MPNST 1, 2, 4, 5, 6 and 8 included in this study [29]. Interestingly, telomerase expression was observed in all tumors except for MPNST 8, which also revealed a long telomere. There is therefore no obvious relationship between telomere length and telomerase activity in MPNSTs, which is consistent with the general observations that the apparent up-regulation of telomerase activity and the presence of shorter telomeres in the majority of tumors [33, 34]. Instead we view the presence of telomerase activity and short telomeres as a marker of a tumor that has transited a telomere driven crisis, that leads to large-scale genomic rearrangements and the upregulation of telomerase activity [24].

It is already known that shortened telomeres play an important role in tumorigenesis in many malignancies [35], including non-small cell lung cancer [36], colorectal 
cancer [37], prostate cancer [38], chronic lymphocytic leukemia [30], breast cancer [39], ovarian cancer [40], and several others. Our data show that the $79 \%$ of the MPNSTs analyzed displayed telomere length distributions within the length ranges at which telomere fusion is detected in CLL [26]. Stratification of CLL and Breast cancer patient cohorts based on these telomere length ranges provide powerful prognostic information $[26,28]$ and it is therefore possible that high-resolution telomere length analysis may also provide prognostic information in MPNSTs. Functional sequence variation in a number of genes involved in telomere maintenance have also been investigated in genetic association studies of common disease and cancer. Sequence variants located within, or immediately adjacent to the TERT gene, are strongly associated with several cancers, notably melanoma, breast, bladder and prostate cancers [41]. Several such TERT promoter mutations, that significantly increase telomerase expression, have been identified in melanomas and several other tumors. However, detailed sequence analysis of the TERT promoter in 96 MPNSTs found that $<10 \%$ showed a specific C228T alteration in the TERT promoter [42], and these tumors were all sporadic (non-NF1-related MPNSTs). Hence, in contrast to other neuroectodermal derived malignant neoplasms, TERT promoter mutations occur infrequently in MPNST.

MPNSTs, like other tumors, are often extremely heterogeneous, both at the cellular and molecular levels $[43,44]$. Indeed, we have shown that more than three-quarters of all MPNSTs display a degree of intratumoral molecular heterogeneity, as evidenced from the differences in the loss-of-heterozygosity ( $\mathrm{LOH}$ ) levels found in different regions of the same tumor [43]. The significant molecular heterogeneity evident at many different gene loci in this study clearly indicates the need to be able to integrate both molecular and morphological biomarkers in early MPNST diagnosis. The bimodal distribution of telomere length observed in different MPNSTs found in this present study, further reflects this genetic and cellular heterogeneity. The heterogeneity of telomere length profiles can reflect the clonal composition of the sample analysed, however we consider that the clear bimodal distributions observed in MPNSTs is more likely a function of purity of the sample ie the presence of both tumor and normal tissue, this cellular and molecular heterogeneity has been reported.

Many human cancers exhibit shortened telomeres and this is consistent with the increased cell division often observed during tumor progression. Telomere fusion and genomic instability, usually related to tumor progression, has been found in several tumor types $[26,37,45]$. The MPNSTs found to harbor short telomeres in this study, were already known to exhibit large-scale genomic rearrangements (Table1) [11, 12, 15], a feature absent from other benign cutaneous and plexiform neurofibromas tumors, which predominantly show long telomeres. Such genomic instability is found in human breast cancers, where short telomeres are implicated in the progression from benign ductal carcinoma to malignant ductal carcinoma $[46,47,28]$, and are also observed in several hematological cancers [48].

Genomic alterations to many other chromosomal regions have been reported in NF1-MPNSTs. Such alterations often involve the cell cycle genes TP53, $C D K N 2 A$ and $R B[1,49]$, with frequent deletions of the 9p21 region containing the CDKN2A (p16) (5053). Frequent loss of the $17 \mathrm{p} 13$ region, encompassing the TP53 gene, has also been found in NF1-MPNSTs [54,55], soft tissue sarcomas and other cancers [56,57]. Furthermore, aberrant expression of several proteins of the $\mathrm{Rb}$ pathway has been found in soft tissue sarcomas, including MPNSTs [53]. In the present study 5/9 MPNSTs with shortened telomeres also exhibited LOH at the TP53 locus (Table 1). Based on our small dataset it is difficult to provide definitive correlations in NF1-associated MPNSTs between short telomeres and large-scale genomic instability. However, these observations are consistent with the hypothesis that telomere dysfunction during the progression of MPNSTs, but not plexiform neurofibromas or cutaneous neurofibromas, may drive large-scale genome instability and acquisition of specific genomic mutations that facilitate progression. Clearly further analysis is required to assess the full extent of telomere dysfunction and fusion in these tumors and to assess the prognostic and predictive potential of high-resolution telomere length analysis.

\section{MATERIALS AND METHODS}

19 macrodissected MPNSTs were obtained from 19 unrelated patients, in addition 10 diffused plexiform and 10 cutaneous neurofibromas were also taken from 20 unrelated NF1 patients. The samples used in this study were provided by genetic centers in Cardiff (UK), London (UK), Toronto (Canada) and Hamburg (Germany). The MPNSTs were classified in accordance with the WHO classification scheme [58] and FNCLCC (French Federation Nationale des Centres de Lutte Contre le Cancer system). Reports on MPNSTs included in this study have previously been published although in order to maintain confidentiality, the identity of tumors is coded $[11,12,15,29,31,32]$. DNA was extracted from fresh frozen tissue as previously reported [11] and analyzed using Single Telomere Length Analysis (STELA) [59]. This project received the full approval of the local Ethics committee. Tumor DNA was extracted and the STELA reactions at the $\mathrm{Xp} / \mathrm{Yp}$ telomeres were carried out as previously described [30]. Following DNA quantification (in triplicate) by Hoechst 33258 fluorometry (BioRad, Hemel Hempstead, UK), the genomic DNA was initially diluted to $10 \mathrm{ng} / \mu \mathrm{l}$ in $10 \mathrm{mM}$ Tris- $\mathrm{HCl}(\mathrm{pH}$ 7.5) and then further diluted to $250 \mathrm{pg} / \mu \mathrm{l}$ in a volume of $40 \mu \mathrm{l}$ that 
contained $1 \mu \mathrm{M}$ Telorette2 linker and $1 \mathrm{mM}$ Tris- $\mathrm{HCl}(\mathrm{pH}$ 7.5). Multiple PCRs were carried out for each test DNA in $10 \mu \mathrm{l}$ volumes, containing $250 \mathrm{pg}$ of diluted DNA, $0.5 \mu \mathrm{M}$ of the telomere-adjacent and Teltail primers, $75 \mathrm{mM}$ Tris$\mathrm{HCl}$ (pH 8.8), 20 mM (NH4) $)_{2} \mathrm{SO} 4,0.01 \%$ Tween-20, 1.5 $\mathrm{mM} \mathrm{MgCl}$, and $0.5 \mathrm{U}$ of a 10:1 mixture of Taq (ABGene, Epsom, UK) and Pwo polymerase (Roche Diagnostics, West Sussex, UK). The reactions were cycled with an MJ PTC-225 thermocycler as described previously [30]. The DNA fragments were resolved by $0.5 \%$ TAE agarose gel electrophoresis, and detected Southern hybridisation with a random-primed $\left[\alpha^{-33} \mathrm{P}\right]$ labelled (PerkinElmer, Coventry, UK) telomere repeat containing probe together with a probe to detect the $1 \mathrm{~kb}$ (Stratagene, La Jolla, CA, USA) and $2.5 \mathrm{~kb}$ (BioRad, Hemel Hempstead, UK) molecular weight markers. The hybridised fragments were detected by phosphorimaging with a Typhoon FLA 9500 phosphorimager (GE Healthcare, St Giles, UK). The molecular weights of the DNA fragments were calculated using the Phoretix 1D quantifier (Nonlinear Dynamics, Newcastle-upon-Tyne, UK).

Statistical comparisons were made using the nonparametric Mann Whitney tests (Prism 6).

\section{ACKNOWLEDGMENTS}

This work was supported by Cancer Research UK (C17199/A18246). We thank Professor Victor Mautner, Professor Ros Ferner and late Professor A Guha for the donation of tumor samples.

\section{CONFLICTS OF INTEREST}

The authors have declared that there is no conflict of interest.

\section{Editorial note}

This paper has been accepted based in part on peerreview conducted by another journal and the authors' response and revisions as well as expedited peer-review in Oncotarget.

\section{REFERENCES}

1. Brems H, Beert E, de Ravel T, Legius E. Mechanisms in the pathogenesis of malignant tumours in neurofibromatosis type 1. Lancet Oncol. 2009; 10:508-15.

2. Evans DG, Baser ME, McGaughran H, Sharif S, Howard E, Moran A. Malignant Peripheral Nerve Sheath Tumours in Neurofibromatosis Type 1. Journal of Medical Genetics. 2002; 39:311-14.

3. Spurlock G, Knight SJ, Thomas N, Kiehl TR, Guha A, Upadhyaya M. Molecular evolution of a neurofibroma to a malignant peripheral nerve sheath tumour (MPNST) in an
NF1 patient:correlation between histopathological, clinical and molecular findings. J Cancer Res Clin Oncol. 2010; 136:1869-80.

4. Beert E, Brems H, Daniëls B, De Wever I, Van Calenbergh F, Schoenaers J, Debiec-Rychter M, Gevaert O, De Raedt T, Van Den Bruel A, de Ravel T, Cichowski K, Kluwe L, et al. Atypical neurofibromas in neurofibromatosis type 1 are premalignant tumors. Genes Chromosomes Cancer. 2011; 50:1021-32.

5. Upadhyaya M, Cooper DN. Neurofibromatosis type 1; molecular and cellular biology. Upadhyaya and Cooper, Springer. 2012.

6. Tucker T, Wolkenstein P, Revuz J, Zeller J, Friedman J. Association between benign and malignant peripheral nerve sheath tumors in NF1. Neurology. 2005; 5:205-11.

7. Mautner VF, Kluwe L, Friedrich RE, Roehl AC, Bammert S, Högel J, Spöri H, Cooper DN, Kehrer-Sawatzki H. Clinical characterisation of 29 neurofibromatosis type-1 patients with molecularly ascertained $1.4 \mathrm{Mb}$ type- $1 \mathrm{NF} 1$ deletions. J Med Genet. 2010; 47:623-30.

8. Ferner RE, Hughes RA, Hall SM, Upadhyaya M, Johnson MR. Neurofibromatous neuropathy in neurofibromatosis 1 (NF1). J Med Genet. 2004; 41:837-41.

9. Evans DG, Huson SM, Birch JM. Malignant peripheral nerve sheath tumours in inherited disease. Clin Sarcoma Res. 2012; 2:17.

10. Miller SJ, Rangwala F, Williams J, Ackerman P, Kong S, Jegga AG, Kaiser S, Aronow BJ, Frahm S, Kluwe L, Mautner V, Upadhyaya M, Muir D, et al. Large-scale molecular comparison of human schwann cells to malignant peripheral nerve sheath tumor cell lines and tissues. Cancer Res. 2006; 66:2584-91.

11. Mantripragada KK, Spurlock G, Kluwe L, Chuzhanova N, Ferner RE, Frayling IM, Dumanski JP, Guha A, Mautner V, Upadhyaya M. High-resolution DNA copy number profiling of malignant peripheral nerve sheath tumors using targeted microarray-based comparative genomic hybridization. Clin Cancer Res. 2008; 14:1015-24.

12. Mantripragada KK, Díaz de Ståhl T, Patridge C, Menzel U, Andersson R, Chuzhanova N, Kluwe L, Guha A, Mautner V, Dumanski JP, Upadhyaya M. Genome-wide highresolution analysis of DNA copy number alterations in NF1-associated malignant peripheral nerve sheath tumors using 32K BAC array. Genes Chromosomes Cancer. 2009; 48:897-907.

13. Miller SJ, Jessen WJ, Mehta T, Hardiman A, Sites E, Kaiser S, Jegga AG, Li H, Upadhyaya M, Giovannini M, Muir D, Wallace MR, Lopez E, et al. Integrative genomic analyses of neurofibromatosis tumours identify SOX9 as a biomarker and survival gene. EMBO Mol Med. 2009; 1:236-48.

14. Hummel TR, Jessen WJ, Miller SJ, Kluwe L, Mautner VF, Wallace MR, Lázaro C, Page GP, Worley PF, Aronow BJ, Schorry EK, Ratner N. Gene expression analysis identifies potential biomarkers of neurofibromatosis type 1 including 
adrenomedullin. Clin Cancer Res. 2010; 16:5048-57.

15. Upadhyaya M, Spurlock G, Thomas L, Thomas NS, Richards M, Mautner VF, Cooper DN, Guha A, Yan J. Microarray-based copy number analysis of neurofibromatosis type-1 (NF1)-associated malignant peripheral nerve sheath tumors reveals a role for RhoGTPase pathway genes in NF1 tumorigenesis. Hum Mutat. 2012; 33:763-76.

16. Meany H, Dombi E, Reynolds J, Whatley M, Kurwa A, Tsokos M, Salzer W, Gillespie A, Baldwin A, Derdak J, Widemann B. 18-fluorodeoxyglucose-positron emission tomography (FDG-PET) evaluation of nodular lesions in patients with Neurofibromatosis type 1 and plexiform neurofibromas (PN) or malignant peripheral nerve sheath tumors (MPNST). Pediatr Blood Cancer. 2013; 60:59-64.

17. Mo W, Chen J, Patel A, Zhang L, Chau V, Li Y, Cho W, Lim K, Xu J, Lazar AJ, Creighton CJ, Bolshakov S, McKay RM, et al. CXCR4/CXCL12 mediate autocrine cell- cycle progression in NF1-associated malignant peripheral nerve sheath tumors. Cell. 2013; 152:1077-90.

18. Rahrmann EP, Watson AL, Keng VW, Choi K, Moriarity BS, Beckmann DA, Wolf NK, Sarver A, Collins MH, Moertel CL, Wallace MR, Gel B, Serra E, et al. Forward genetic screen for malignant peripheral nerve sheath tumor formation identifies new genes and pathways driving tumorigenesis. Nat Genet. 2013; 45:756-66.

19. De Raedt T, Beert E, Pasmant E, Luscan A, Brems H, Ortonne N, Helin K, Hornick JL, Mautner V, KehrerSawatzki H, Clapp W, Bradner J, Vidaud M, et al. PRC2 loss amplifies Ras-driven transcription and confers sensitivity to BRD4-based therapies. Nature. 2014; 514:247-51.

20. Lee W, Teckie S, Wiesner T, Ran L, Prieto Granada CN, Lin M, Zhu S, Cao Z, Liang Y, Sboner A, Tap WD, Fletcher JA, Huberman KH, et al. PRC2 is recurrently inactivated through EED or SUZ12 loss in malignant peripheral nerve sheath tumors. Nat Genet. 2014; 46:1227-32.

21. Zhang M, Wang Y, Jones S, Sausen M, McMahon K, Sharma R, Wang Q, Belzberg AJ, Chaichana K, Gallia GL, Gokaslan ZL, Riggins GJ, Wolinksy JP, et al. Somatic mutations of SUZ12 in malignant peripheral nerve sheath tumors. Nat Genet. 2014; 46:1170-2.

22. de Lange T. Shelterin: The protein complex that shapes and safeguards human telomeres. Genes Dev. 2005; 19:2100 2110.

23. Counter CM, Avilion AA, LeFeuvre CE, Stewart NG, Greider CW, Harley CB, Bacchetti S. Telomere shortening associated with chromosome instability is arrested in immortal cells which express telomerase activity. EMBO J. 1992; 11:1921-9.

24. Jones RE, Oh S, Grimstead JW, Zimbric J, Roger L, Heppel $\mathrm{NH}$, Ashelford KE, Liddiard K, Hendrickson EA, Baird DM. Escape from telomere-driven crisis is DNA ligase III dependent. Cell Rep. 2014; 8:1063-76.
25. Artandi SE, Chang S, Lee SL, Alson S, Gottlieb GJ, Chin L, DePinho RA. Telomere dysfunction promotes nonreciprocal translocations and epithelial cancers in mice. Nature. 2000; 406: 641-645.

26. Lin TT, Norris K, Heppel NH, Pratt G, Allan JM, Allsup DJ, Bailey J, Cawkwell L, Hills R, Grimstead JW, Jones RE, Britt-Compton B, Fegan C, et al. Telomere dysfunction accurately predicts clinical outcome in chronic lymphocytic leukaemia, even in patients with early stage disease. Br J Haematol. 2014; 167:214-223.

27. Strefford JC, Kadalayi L, Forster J, Rose-Zerilli MJ, Parker A, Lin TT, Heppel NH, Norris K, Gardiner A, Davies Z, Gonzalez de Castro D, Else M, Steele AJ, et al. Telomere length predicts progression and overall survival in chronic lymphocytic leukemia: data from the UK LRF CLL4 trial. Leukemia. 2015; 29:2411-14.

28. Simpson K, Jones RE, Grimstead JW, Hills R, Pepper C, Baird DM. Telomere fusion threshold identifies a poor prognostic subset of breast cancer patients. Mol Oncol. 2015; 9:1186-1193.

29. Mantripragada KK, Caley M, Stephens P, Jones CJ, Kluwe L, Guha A, Mautner V, Upadhyaya M. Telomerase activity is a biomarker for high grade malignant peripheral nerve sheath tumors in neurofibromatosis type 1 individuals. Genes Chromosomes Cancer. 2008; 47:238-46.

30. Lin TT, Letsolo BT, Jones RE, Rowson J, Pratt G, Hewamana S, Fegan C, Pepper C, Baird DM. Telomere dysfunction and fusion during the progression of chronic lymphocytic leukemia:evidence for a telomere crisis. Blood. 2010; 116:1899-1907.

31. Spurlock G, Griffiths S, Uff J, Upadhyaya M. Somatic alterations of the NF1 gene in an NF1 individual with multiple benign tumours (internal and external) and malignant tumour types. Fam Cancer. 2007; 6:463-71.

32. Upadhyaya M, Kluwe L, Spurlock G, Monem B, Majounie E, Mantripragada K, Ruggieri M, Chuzhanova N, Evans DG, Ferner R, Thomas N, Guha A, Mautner V. Germline and somatic NF1 gene mutation spectrum in NF1-associated malignant peripheral nerve sheath tumours (MPNSTs). Hum Mutat. 2008; 29:74-82.

33. Kim NW, Piatyszek MA, Prowse KR, Harley CB, West MD, Ho PL, Coviello GM, Wright WE, Weinrich SL, Shay JW. Specific association of human telomere activity with immortal cells and culture. Science. 1994; 266:2011-5.

34. Hastie ND, Dempster M, Dunlop MG, Thompson M, Green DK, Allshire RC. Telomere reduction in human colorectal carcinoma and with ageing. Nature. 1990; 346:866-8.

35. Zhu X, Han W, Xue W, Zon Y, Xie C, Du J, Jin G. The association between telomere length and cancer risk in population studied. Sci Rep. 2016; 6:222.

36. Frías C, García-Aranda C, De Juan C, Morán A, Ortega P, Gómez A, Hernando F, López-Asenjo JA, Torres AJ, Benito M, Iniesta P. Telomere shortening is associated with poor prognosis and telomerase activity correlates with 
DNA repair impairment in non-small cell lung cancer. Lung Cancer. 2008; 60:416-425.

37. Roger LR, Jones E, Heppel NH, Williams GT, Sampson JR, Baird DM. Extensive telomere erosion in the initiation of colorectal adenomas and its association with chromosomal instability. J Natl Cancer Inst. 2013; 105:1202-1211.

38. Hurwitz LM, Heaphy CM, Joshu CE, Isaacs WB, Konishi Y, De Marzo AM, Isaacs SD, Wiley KE, Platz EA, Meeker AK. Telomere length as a risk factor for hereditary prostate cancer. Prostate. 2014; 74:359-64.

39. Zhou X, Meeker AK, Makambi KH, Kosti O, Kallakury BV, Sidawy MK, Loffredo CA, Zheng YL. Telomere length variation in normal epithelial cells adjacent to tumor: potential biomarker for breast cancer local recurrence. Carcinogenesis. 2012; 33:113-8.

40. Terry KL, Tworoger SS, Vitonis AF, Wong J, TitusErnstoff L, De Vivo I, Cramer DW. Telomere length and genetic variation in telomere maintenance genes in relation to ovarian cancer risk. Cancer Epidemiol Biomarkers Prev. 2012; 21:504-12.

41. Barrett JH, Iles MM, Dunning AM, Pooley K. Telomere length and common disease: study design and analytical challenges. Hum Genetics. 2015; 134:679-689.

42. Dubbink HJ, Bakels H, Post E, Zwarthoff EC, Verdijk RM. TERT promoter mutations and BRAF mutations are rare in sporadic, and TERT promoter mutations are absent in NF1-related malignant peripheral nerve sheath tumours. J Neurooncol. 2014; 120:267-72.

43. Thomas L, Mautner VF, Cooper D, Upadhyaya M. Molecular Heterogeneity in Malignant Peripheral Nerve Sheath Tumors (MPNSTs) Associated with Neurofibromatosis Type 1 (NF1). Hum Genomics. 2012; 6:18-27.

44. Gerlinger M, Rowan AJ, Horswell S, Larkin J, Endesfelder D, Gronroos E, Martinez P, Matthews N, Stewart A, Tarpey $\mathrm{P}$, Varela I, Phillimore B, Begum S, et al. Intratumor heterogeneity and branched evolution revealed by multiregion sequencing. N Engl J Med. 2012; 366:883-92.

45. Jones CH, Pepper C, Baird DM. Telomere dysfunction and its role in haematological cancer. Br J Haematol. 2012; 156:573-87.

46. Chin K, de Solorzano CO, Knowles D, Jones A, Chou W, Rodriguez EG, Kuo WL, Ljung BM, Chew K, Myambo K, Miranda M, Krig S, Garbe J, et al. In situ analyses of genome instability in breast cancer. Nat Genet. 2004; 36:984-8.

47. Meeker AK, Argani P. Telomere shortening occurs early during breast tumorigenesis: a cause of chromosome destabilization underlying malignant transformation? J Mammary Gland Biol Neoplasia. 2004; 9:285-96.
48. Pepper C, Baird DM. Shortened telomeres:a driving force behind leukemia? Future Oncology. 2010; 6:1681- 1686.

49. Cichowski K, Jacks T. NF1 tumor suppressor gene function: narrowing the GAP. Cell. 2001; 104:593-604.

50. Nielsen GP, Stemmer-Rachamimov AO, Ino Y, Moller MB, Rosenberg AE, Louis DN. Malignant transformation of neurofibromas in neurofibromatosis 1 is associated with CDKN2A/p16 inactivation. Am J Pathol. 1999; 155:187984.

51. Perrone F, Tabano S, Colombo F, Dagrada G, Birindelli S, Gronchi A, Colecchia M, Pierotti MA, Pilotti S. p15INK4b, p14ARF, and p16INK4a inactivation in sporadic and neurofibromatosis type 1-related malignant peripheral nerve sheath tumors. Clin Cancer Res. 2003; 9:4132-8.

52. Frahms S, Mautner V, Brems L, Legius E, DebiecRychter M, Friedrich RE, Knofel WT, Peiper M, Kluwe L. Genetic and phenotypic characterisation of tumour cells derived from malignant peripheral nerve sheath tumours of neurofibromatosis type-1 patients. Neurobiol Dis. 2004; 16:85-91.

53. Sabah M, Cummins R, Leader M, Kay E. Loss of p16 (INK4A) expression is associated with allelic imbalance/loss of heterozygosity of chromosome $9 \mathrm{p} 21$ in microdissected malignant peripheral nerve sheath tumors. Appl Immunohistochem Mol Morphol. 2006; 14:97-102.

54. Legius E, Dierick H, Wu R, Hall B, Marynen P, Cassiman $\mathrm{J}$, Glover T. TP53 mutations are frequent in malignant NF1 tumors. Genes Chrom Cancer. 1994; 10:250-255.

55. Verdijk RM, den Bakker MA, Dubbink HJ, Hop WC, Dinjens WN, Kros JM. TP53 mutation analysis of malignant peripheral nerve sheath tumors. J Neuropathol Exp Neurol. 2010; 69:16-26.

56. Latres E, Drobnjak M, Pollack D, Oliva MR, Ramos M, Karpeh M, Woodruff JM, Cordon-Cardo C. Chromosome 17 abnormalities and TP53 mutations in adult soft tissue sarcomas. Am J Pathol. 1994; 145:345-55.

57. Borras C, Gomez-Cabrera MC, Vina J. The dual role of p53: DNA protection and antioxidant. Free Radic Res. 2011; 45:643-652.

58. Woodruff JM, Kourea HP, Louis DN, Scheithauer BW. Malignant nerve sheath tumor (MPNST). In: Kleihues P, Cavenee WK, editors. Pathology and Genetics of Tumours of the Nervous system. Lyon, France: IARC Press. 2000; pp.172-174.

59. Capper R, Britt-Compton B, Tankimanova M, Rowson J, Letsolo B, Man S, Haughton M, Baird DM. The nature of telomere fusion and a definition of the critical telomere length in human cells. Genes Dev. 2007; 21:2495-508. 